\title{
Efektivitas Bukaan pada Rumah Bandayo Pobo'ide Terhadap Kenyamanan Fisiologis
}

\author{
${ }^{1}$ Rahmayanti, ${ }^{2}$ ST.Haisah \\ 1 Universitas Pohuwato, Jl. Trans Sulawesi No.147, Gorontalo, Indonesia \\ 2 Universitas Ichsan Gorontalo, Jl. Raden Saleh No.10, Telp/Fax (0435) 829975, Gorontalo, Indonesia \\ e-mail: rahmayanti.architecture@gmail.com
}

\begin{abstract}
Abstrak
Rumah Bandayo Pobo'ide merupakan salah satu rumah adat di Indonesia yang menggunakan penghawaan alami sebagai pendinginan fisiologis penghuninya. Pada saat ini rumah Bandayo Pobo'ide beralih fungsi dimana pada masa lalu digunakan sebagai rumah tinggal dan wadah dilakukannya upacara adat, sedangkan pada saat ini hanya digunakan untuk upacara adat. Hal ini mempengaruhi kebutuhan penghawaan alami di dalam rumah tersebut. Peran bukaan menjadi faktor utama dalam menghadirkan kenyamanan fisiologis di dalam ruang. Prosentase bukaan yang mampu mengakomodir kenyamanan ruang yakni $40 \%$ dari total luas dinding. Penelitian ini bertujuan mengevaluasi efektifitas bukaan untuk aktifitas masa kini. Pengukuran lapangan dilakukan untuk mengetahui fenomena di dalam dan sekitar Bandayo Pobo'ide. Metode deskriptif digunakan untuk menjelaskan efektifitas bukaan terhadap kenyamanan fisiologis yang akan dihitung berdasarkan WSC (wind support comfort). Hasil penelitian menunjukkan bahwa bukaan yang ada kurang dari $40 \%$, oleh karena itu kecepatan angin di dalam bangunan relatif kecil dan stagnan pada angka $0.1 \mathrm{~m} / \mathrm{s}$.
\end{abstract}

Kata kunci: Bandayo Pobo'ide, Penghawaan alami, Wind Support Comfort

\begin{abstract}
Bandayo Pobo'ide is one of the traditional houses in Indonesia that uses natural ventilation as a physiological cooling. Nowadays, Bandayo Pobo'ide houses are used only for traditional ceremonies. In the past, the houses were used both for residence as well as for conducting traditional ceremonies. This affects the need for natural ventilation in the house. The role of openings is a major factor in providing physiological comfort in space. The percentage of openings that can accommodate the comfort of the room is $40 \%$ of the total wall area. This study aims to evaluate the effectiveness of openings for current activities. Field measurements were carried out to determine the phenomena in and around Bandayo Pobo'ide. Descriptive method was used to explain the effectiveness of the opening against the physiological comfort which will be calculated based on WSC (wind support comfort). The results showed that the openings were less than $40 \%$, therefore the wind speed inside the building was relatively stagnant at $0.1 \mathrm{~m} / \mathrm{s}$.
\end{abstract}

Keywords: Bandayo Pobo'ide, natural ventilation, wind support comfort

Diterima: 11 Oktober 2020

Disetujui: 28 Nopember 2020

Dipublikasi: 16 Desember 2020

(C2020 Rahmayanti, ST.Haisah Under the license CC BY-SA 4.0

\section{Pendahuluan}

Rumah adat di Indonesia pada dasarnya hadir sebagai bentukan yang berasal dari kearifan lokal. Bentukan yang ada merupakan bentukan yang mampu bertahan terhadap iklim setempat melalui proses trial dan error dalam pembangunannya (Mangunwijaya,1992). Sebagai bentuk tanggap terhadap iklim tropis lembab, ciri dari rumah tradisional adalah atap yang tinggi dengan kemiringan yang tajam, dinding dari 
kayu dengan bukaan jendela yang lebar dan lantai yang ditinggikan/panggung (Sukawi, 2009).

Salah satu rumah dengan ciri tersebut adalah rumah adat Bantayo Pobo'ide yang terletak di Gorontalo. Rumah adat Bantayo Pobo'ide merupakan salah satu rumah adat di Indonesia yang menggunakan penghawaan alami sebagai pendinginan fisiologis. Pemanfaatan penghawaan alami pada rumah adat Bantayo Pobo'ide terlihat dengan adanya bukaan sebagai jalan masuknya aliran angin. Hal ini dapat mengurangi penggunaan energi pendinginan di dalam bangunan, dimana bangunan mengkonsumsi energi sebesar $40 \%$ dan $1 / 3$ merupakan emisi gas dari penggunaan penghawaan dan pencahayaan (Asdrubali dalam (Niniek, 2020). Oleh karena itu penghawaan alami merupakan pengontrol kenyamanan bagi manusia karena prosesnya tidak bergantung pada pasokan energi dan instalasi mekanis. Prosentase luas bukaan yang dapat mengakomodir kenyamanan penghuni adalah $40 \%$ dari total luas dinding (Rahmayanti, 2020), akan tetapi bukaan yang ada di rumah adat Bantayo Pobo'ide kurang dari $40 \%$ dari total luas dinding, sehingga perlu dilakukan penelitian sejalan dengan pergeseran fungsi rumah adat itu sendiri.

Penelitian ini berfokus pada bukaan yang ada pada rumah adat Bantayo Pobo'ide. Penelitian sebelumnya telah mengevaluasi kenyamanan termal pada rumah adat ini yang dilakukan oleh Muhdi, dkk (2014) sehingga penelitian ini melengkapi penelitian sebelumnya dengan adanya perhitungan kebutuhan kecepatan angin yang diperlukan untuk pendinginan fisiologis penghuni dan rekomendasi bukaan untuk daerah yang memiliki iklim tropis lembab. Penelitian terkait luasan, posisi dan konfigurasi pada rumah adat Balai Padang telah dilakukan oleh Rahmayanti (2020), dimana pada penelitian tersebut rumah adat yang diteliti memiliki bukaan yang minim, sementara pada penelitian rumah adat Bantayo Pobo'ide memiliki bukaan yang luas.

\section{Metode}

Metode yang digunakan pada penelitian ini adalah metode deskriptif. Data yang didapatkan, melalui pengukuran lapangan dari pukul 08.00-17.00 Wita. Pengukuran dilakukan selama tiga hari berturut-turut, dilakukan di dalam dan diluar bangunan. Pengukuran baik di dalam maupun diluar bangunan dilakukan pada satu titik di waktu yang sama, seperti yang ditunjukkan pada gambar 1. Pemilihan titik pengukuran didasarkan pada posisi ruang yang jauh dari bukaan dan fungsi ruang yang memiliki kepadatan penghuni yaitu ruang resepsi pengantin (puade). Pengukuran di dalam dan diluar menggunakan alat ukur bangunan yang dicatat setiap jam. 

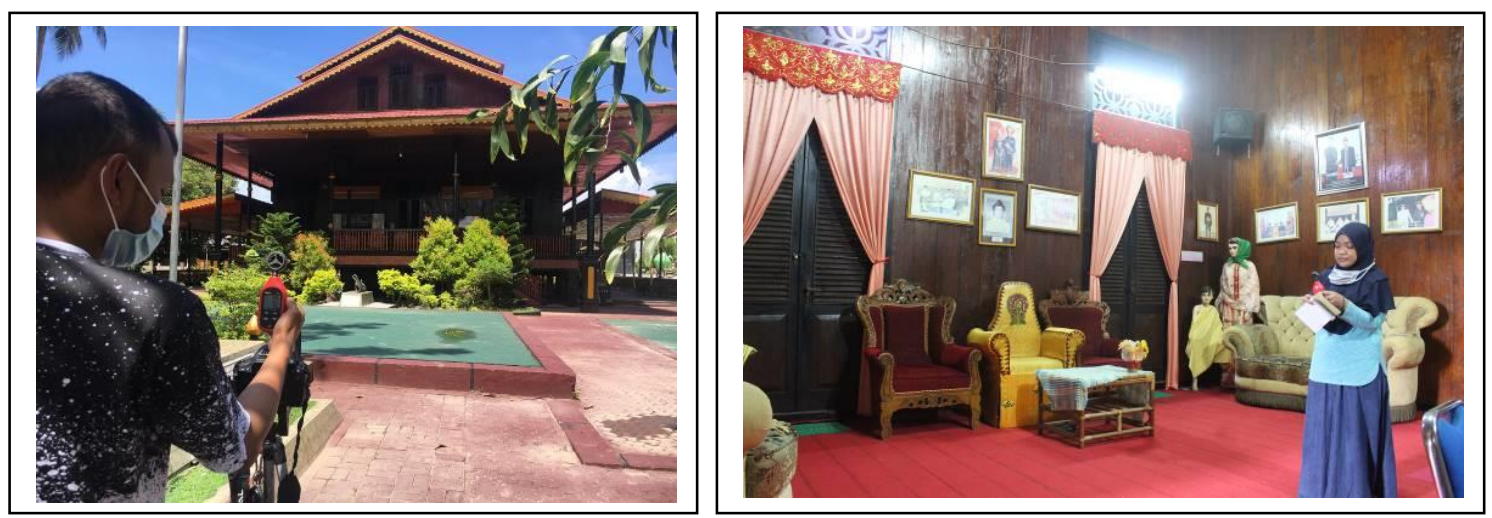

Gambar 1. Titik Ukur diluar dan di dalam bangunan

Adapun yang diukur adalah kecepatan angin menggunakan alat ukur anemometer dengan kemampuan mendeteksi kecepatan angin yakni $0 \mathrm{~m} / \mathrm{s}-30 \mathrm{~m} / \mathrm{s}$, pengukuran suhu menggunakan alat thermometer dengan range temperatur yang dapat dideteksi yakni $-50^{\circ} \mathrm{C}-70^{\circ} \mathrm{C}$. Untuk pengukuran kelembaban relatif digunakan alat hygrometer yang memiliki kemampuan mengukur 10\%-99\%. Masing-masing alat diletakkan pada ketinggian manusia beraktifitas atau 1 meter dari permukaan lantai.

\section{Hasil dan Pembahasan}

\section{Hasil}

Bandayo Pobo'ide merupakan salah satu rumah adat yang terletak di Provinsi Gorontalo, tepatnya di pusat kota Limboto yang merupakan ibu kota kabupaten Gorontalo. Secara geografis terletak pada $0.30^{\circ}-1.0^{\circ}$ LU dan $121^{\circ}-123.3^{\circ} \mathrm{BT}$, artinya berada pada daerah yang beriklim tropis lembab.

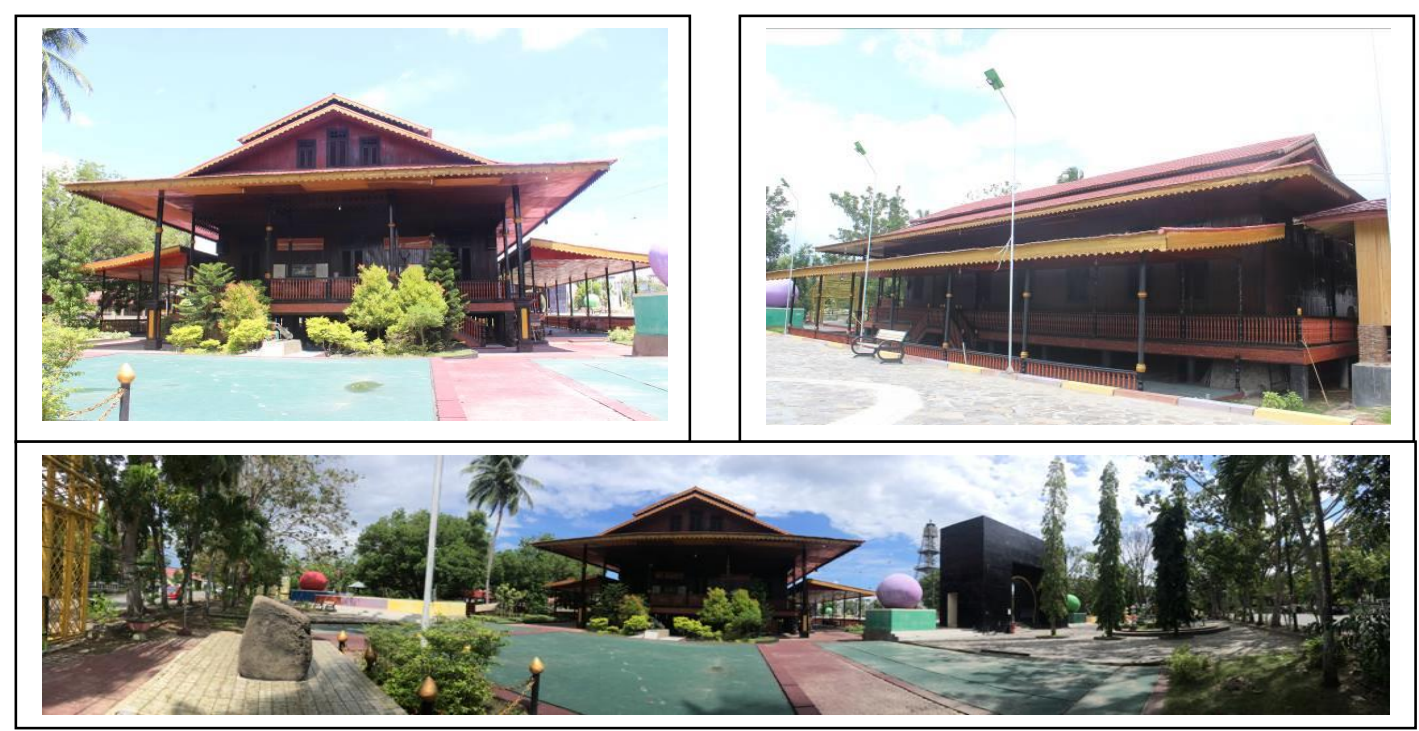

Gambar 2. Tampak dan lingkungan sekitar rumah adat Bandayo Pobo'ide 
Orientasi rumah adat Bandayo Pobo'ide menghadap Utara-Selatan. Pada sisi Timur dan Barat dipenuhi pepohonan yang padat seperti yang ditunjukkan pada gambar 2. Pada sisi Utara terdapat rumah yang merupakan pengembangan rumah Bandayo Pobo'ide, disebelah selatan juga dipenuhi dengan pepohonan.

Rumah Bandayo Pobo'ide adalah rumah satu lantai dengan konstruksi panggung dengan ketinggian kolom yang berbeda yakni 1-1,5 meter. Material yang digunakan terbuat dari kayu, kecuali beberapa tiang penyangga merupakan cor beton. Lantai rumah menggunakan kayu yang dipasang tanpa celah dan dilapisi dengan karpet. Selubung bangunan menggunakan kayu dengan setiap sisinya memiliki daun jendela. Konstruksi atap menggunakan kuda-kuda kayu. Pada bagian atap terdapat plafon, sehingga rangka atap tertutupi.

\section{Kecepatan dan Arah angin serta distribusi aliran udara di dalam ruang}

Berdasarkan hasil pengukuran yang dilakukan selama tiga hari berturut-turut menunjukkan bahwa arah dominan datangnya angin yakni berasal dari Utara dan Timur. Kecepatan angin tertinggi di luar bangunan terjadi pada pukul 10.00, 11.00 dan 14.00 Wita yakni berkisar antara $1.8-2.5 \mathrm{~m} / \mathrm{s}$. Sementara di dalam bangunan relatif kecil, untuk kecepatan angin didekat bukaan (gambar 3), kecepatan angin berkisar antara $0.4-0.8 \mathrm{~m} / \mathrm{s}$, sedangkan kecepatan angin di ruang tengah (ruang pengantin) memiliki kecepatan angin $0.1 \mathrm{~m} / \mathrm{s}$ atau hampir tidak dapat dirasakan. Pengukuran kecepatan angin yang dekat dengan bukaan dilakukan untuk mengetahui kecepatan angin yang sampai pada bukaan, sehingga dapat diketahui fenomena yang terjadi pada ruang tengah.

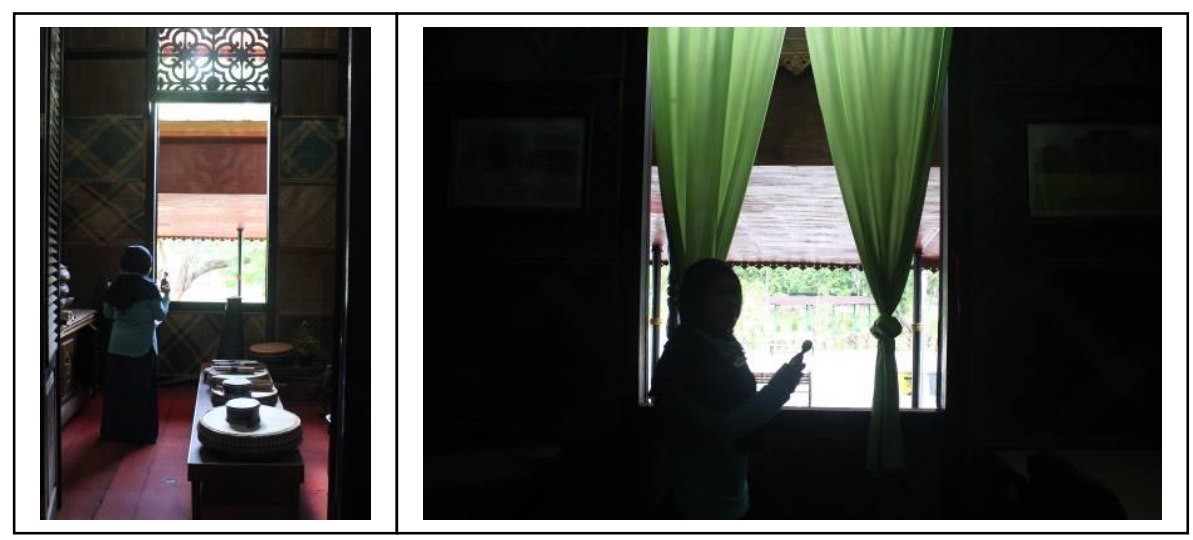

Gambar 3. Pengukuran dekat dengan bukaan sisi Barat (kiri) sisi Timur (kanan)

Gambar 4 menunjukkan bahwa perbandingan kecepatan angin diluar dan di dalam bangunan memiliki perbedaan yang sangat signifikan. Kecepatan angin diluar bangunan terlihat variatif, sedangkan kecepatan angin di dalam bangunan terlihat 
stagnan. Hasil pengukuran kecepatan angin diluar bangunan berkisar antara $0.3 \mathrm{~m} / \mathrm{s}$ $2.5 \mathrm{~m} / \mathrm{s}$. Sementara kecepatan angin di dalam bangunan (ruang tengah) stagnan pada angka $0.1 \mathrm{~m} / \mathrm{s}$. Hal ini menjadi salah satu faktor ketidaknyamanan di dalam ruang untuk melakukan aktifitas.

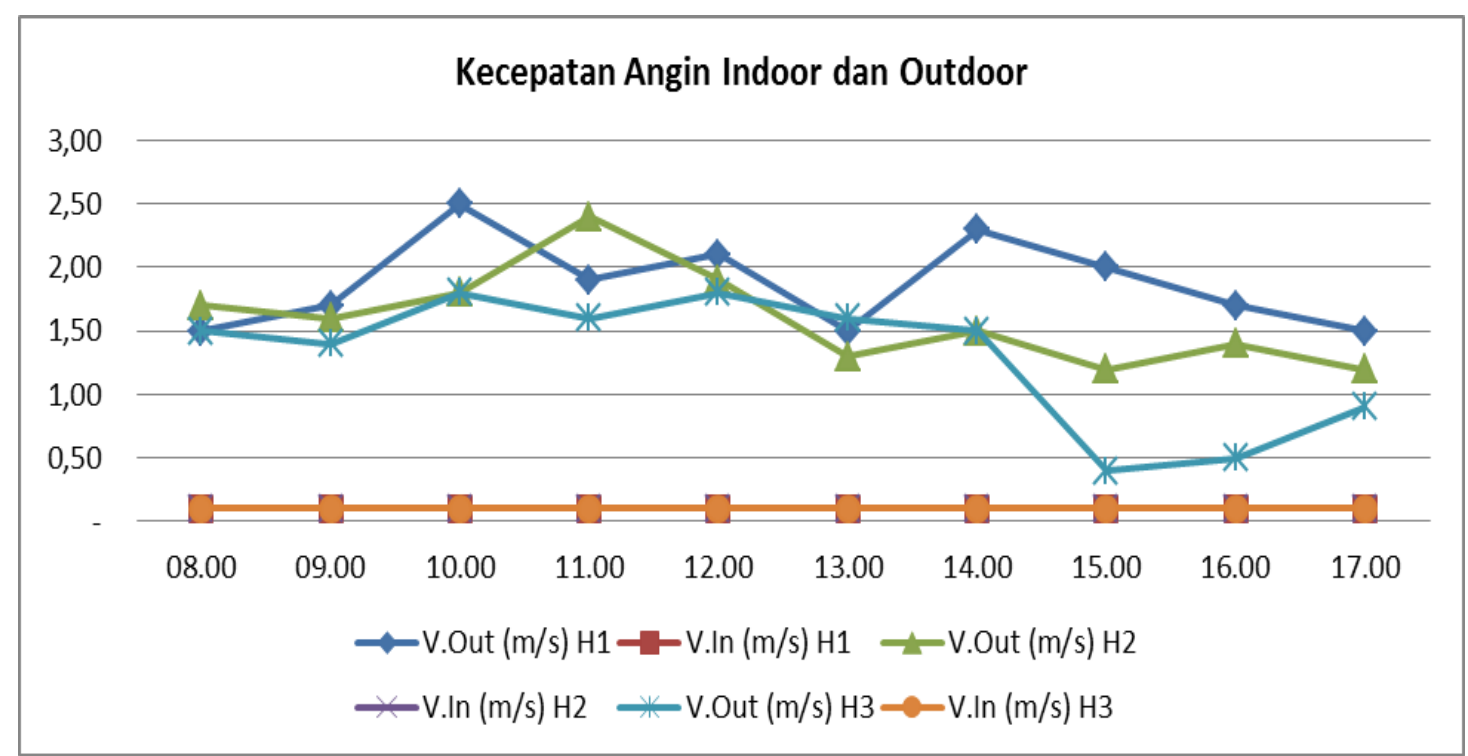

Gambar 4. Kecepatan Angin Indoor dan Outdoor

\section{Nilai Temperatur Indoor dan Outdoor}

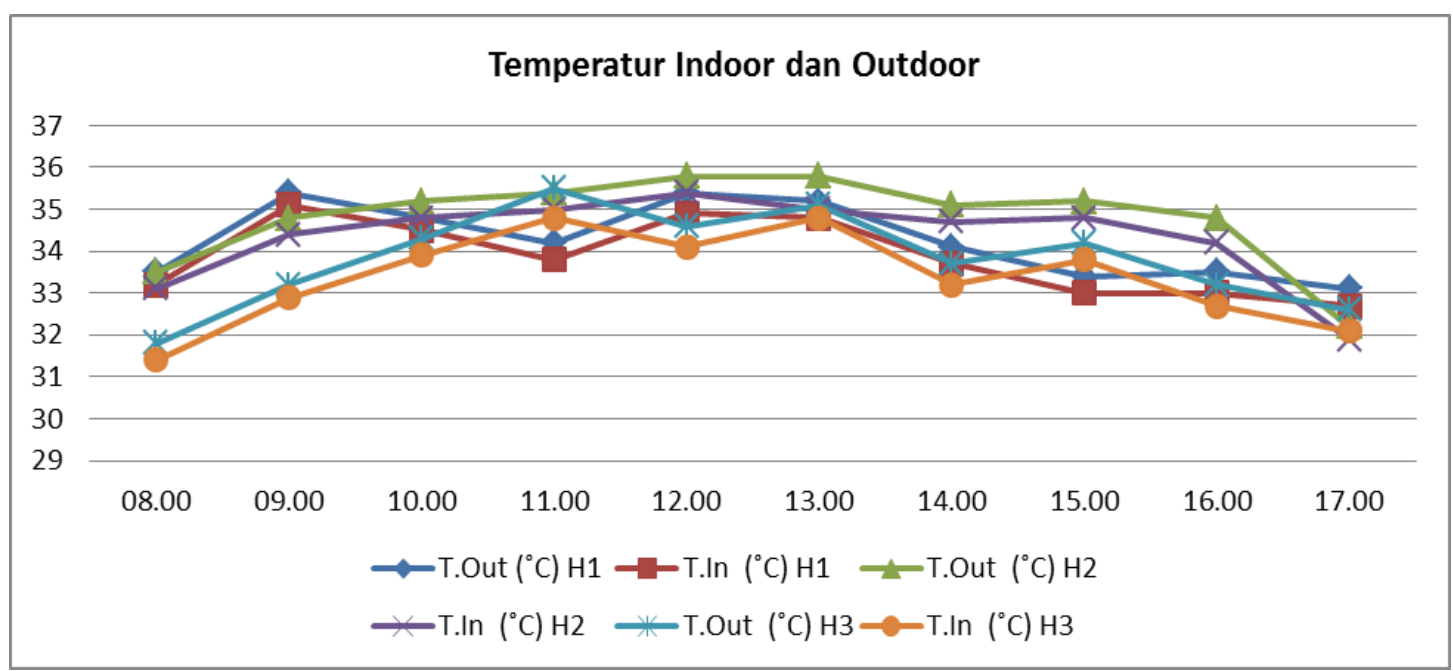

Gambar 5. Temperatur Udara Indoor dan Outdoor

Berdasarkan hasil pengukuran, nilai temperatur udara diluar dan di dalam ruang tidak jauh berbeda yakni hanya berkisar antara $0.3-0.7^{\circ} \mathrm{C}$. Nilai temperatur udara tertinggi berada pada pukul 09.00-13.00 Wita yaitu 32.1-35.8ㅇ seperti yang ditunjukkan pada gambar 5 . Hal ini tentu menjadikan penghuni/pengguna bangunan menjadi tidak nyaman. Tingginya suhu udara merupakan salah satu ciri dari iklim tropis lembab. Perbedaan suhu udara di dalam dan diluar bangunan yang tidak signifikan 
disebabkan oleh bukaan yang luas, sehingga mempengaruhi suhu konvektif ruang akbiatnya suhu resultan dalam ruang tidak berbeda jauh.

\section{Nilai Kelembaban Relatif (RH) Indoor dan Outdoor}

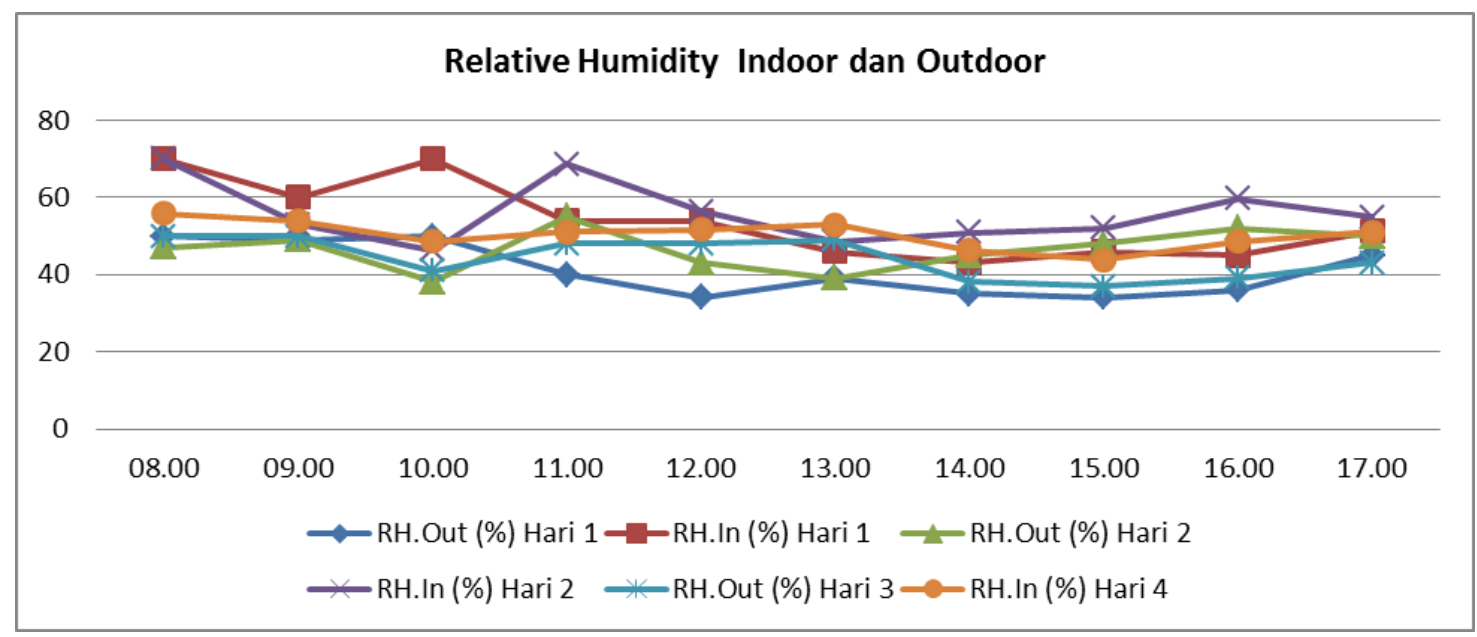

Gambar 6. Kelembaban Udara Indoor dan Outdoor

Nilai kelembaban relatif dari hasil pengukuran ditunjukkan pada gambar 6 , terlihat bahwa nilai kelembaban relatif diluar dan di dalam bangunan memiliki perbedaan yang tidak terlalu signifikan. Nilai kelembaban relatif di dalam bangunan berkisar $45-70 \%$ sedangkan diluar bangunan memiliki nilai antara $34-55 \%$. $\mathrm{RH}$ di dalam bangunan memiliki angka yang lebih tinggi dibanding diluar bangunan, hal ini disebabkan karena kecepatan angin di dalam bangunan kecil, sehingga udara banyak mengandung air, sedangkan diluar bangunan, kondisi kecepatan angin cukup besar dan suhu udara tinggi sehingga kandungan air di dalam udara menjadi sedikit.

\section{Pembahasan}

Pengaruh Luas bukaan terhadap kecepatan angin, temperatur dan kelembaban relatif

Luas bukaan menjadi salah satu faktor penting dalam perolehan aliran angin yang masuk ke dalam bangunan yang berfungsi untuk menghapus panas dan kelembaban. Menurut Allard, (1998) ventilasi silang yang baik adalah bukaan yang memiliki ukuran inlet (jalan masuknya angin) outlet (jalan keluarnya angin) sama. Sejalan dengan hal tersebut, Allard (1998) dan Rahmayanti (2020) mengemukakan bahwa ukuran bukaan yang mampu mengakomodir kecepatan angin yakni memiliki rasio $40 \%$ dari total luas dinding.

Pada rumah adat Bandayo Pobo'ide bukaan berupa pintu, jendela dan lubang angin. Berdasarkan arah angin dari Utara dan Timur maka yang berfungsi sebagai inlet adalah jendela pada setiap sisinya dan outlet adalah pintu, sehingga ukuran inlet lebih 
kecil dibandingkan ukuran outlet. Ukuran outlet yang lebih kecil menyebabkan hisapan angin pada sisi Oleh karena itu, kecepatan angin yang masuk hingga keruang tengah menjadi berkurang.

Adapun window to wall ratio pada fasad Utara sebesar $7 \%$, karena pada fasad ini bukaan hanya berupa pintu, sehingga pada saat arah angin berasal dari utara maka kecepatan angin yang masuk ke dalam bangunan menjadi kecil, faktor lain yang mempengaruhi kecepatan angin menjadi kecil yaitu adanya bangunan disisi utara yang memiliki jarak yang dekat dengan bukaan sehingga menghalangi aliran angin mencapai bukaan. Sementara pada fasad Timur rasio luas dinding dan luas bukaan sebesar $31 \%$, akan tetapi kecepatan angin yang masuk ke dalam bangunan tetap sama yaitu kecil. Hal ini disebabkan oleh keberadaan penghalang berupa atap dari ruang serambi disebelahnya yang mana posisi atap sejajar dengan posisi bukaan, sehingga kecepatan angin yang masuk melalui bukaan sudah berkurang sebesar 50 $60 \%$ dari kecepatan angin diawal disebabkan mengalami tumbukan dan gesekan benda padat (atap bangunan), (Boutet,1987).

Selain faktor eksternal, faktor internal yang mempengaruhi kecepatan angin berkurang atau relatif kecil yakni ukuran ruang yang besar menyebabkan jarak jangkauan angin dari inlet menuju outlet cukup panjang, sehingga tekanan angin mencapai pada fase terminal region artinya angin kehilangan tekanan akibat bergesekan dengan udara di dalam ruang (Ansley,1977). Selain itu, adanya partisi yang turut menghalangi aliran angin menuju ke ruang setelahnya, (Givoni, 1976)

\section{Pengaruh kecepatan angin terhadap kenyamanan fisiologis}

Salah satu fungsi dari ventilasi alami adalah untuk menghapus panas dari badan penghuni agar tercapai kenyamanan fisiologis. Sebagaimana hal tersebut, maka dilakukan perhitungan kecepatan angin yang direkomendasikan oleh Mc Farlen dalam Ansley (1977) untuk wind support comfort. Pada gambar 7 menunjukkan angka perbandingan antara kecepatan angin hasil pengukuran dengan kecepatan angin hasil perhitungan. Dalam grafik tersebut menunjukkan bahwa kecepatan angin yang ada di dalam rumah adat Bandayo Pobo'ide memiliki nilai dibawah dari kecepatan angin yang dibutuhkan. Oleh karena itu, efektifitas bukaan pada rumah tersebut belum mampu mengakomodir kenyamanan fisiologis penghuni. Ketidaknyamanan tersebut dipengaruhi oleh suhu dan kelembaban udara yang tinggi. 


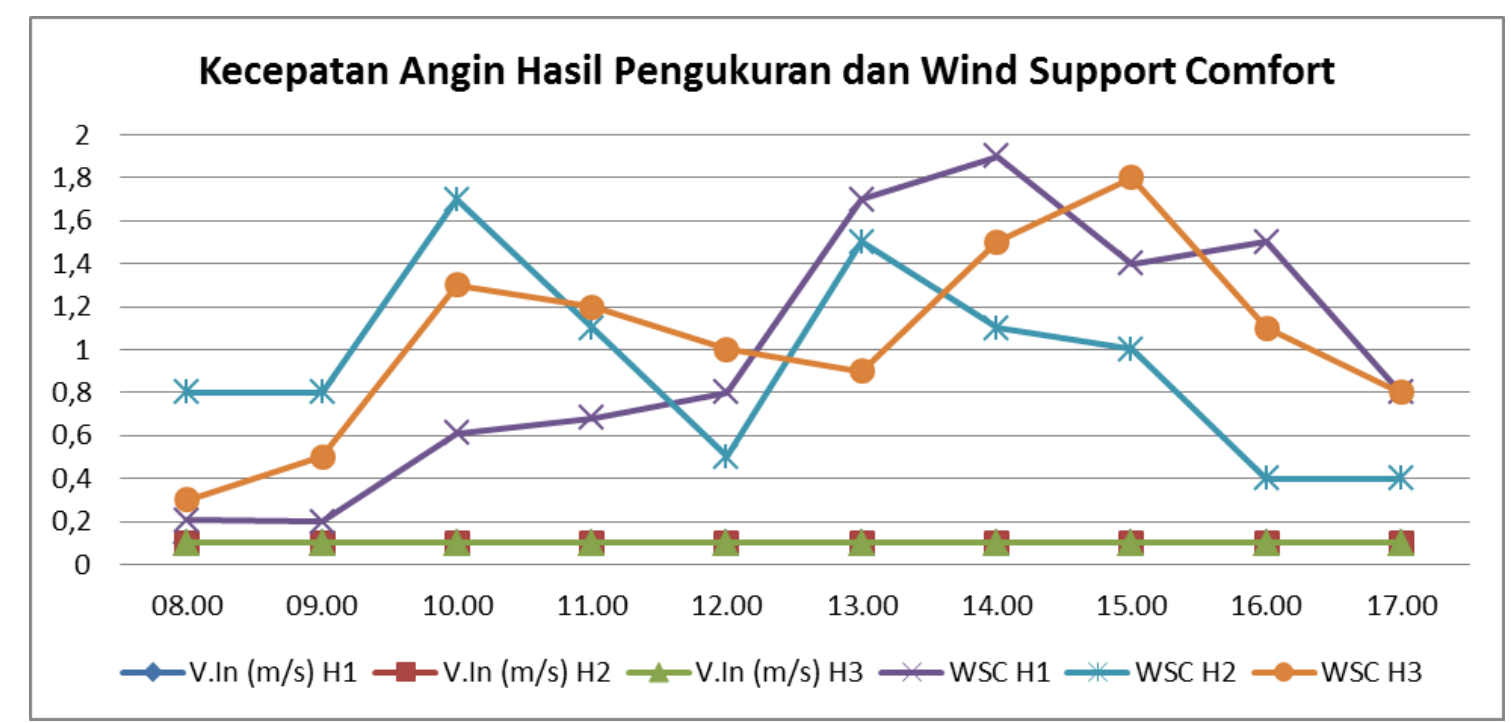

Gambar 7. Grafik Perbandingan kecepatan angin hasil pengukuran dan kecepatan angin yang dibutuhkan untuk kenyamanan fisiologis.

\section{Kesimpulan}

Rendahnya nilai kecepatan angin di dalam bangunan dipengaruhi oleh dua faktor yaitu faktor eksternal dan internal. Faktor eksternal adalah kecepatan dan arah angin. Utara dan Timur merupakan arah dominan angin menyebabkan angin tidak dapat mencapai bukaan dengan maksimal, disebabkan adanya bangunan pada kedua sisi fasad tersebut. Faktor internal yaitu luasnya ruang dan adanya penghalang. Sementara luas bukaan juga hanya mencapai 31\% dari total luas dinding. Oleh karena itu, diperlukan penelitian selanjutnya dengan melakukan simulasi dengan menambah WWR menjadi 40\%, sebagaimana rekomendasi penelitian terdahulu.

Metode perhitungan kebutuhan angin menggunakan wind support comfort membuktikan bahwa kecepatan angin di dalam bangunan belum dapat mengakomodir kenyamanan fisiologis. Oleh karena itu, bukaan yang ada pada rumah adat Bandayo belum dapat direkomendasikan/menjadi rujukan untuk bangunan rumah yang memiliki ukuran besar.

\section{Daftar Pustaka}

Allard, F. (1998). Natural ventilation building-a design handbook. London: James and James Science Publishers.

Ansley, Melbourne and Vickery. (1977). Architectural aerodynamics. London: Applied Science Publishers LTD.

Boutet, T.S. (1987). Controling air movement, manual for architect and building. United State of America: McGraw-Hill.

Givoni, B. (1998). Climate considerations building and urban design. New York: Van Nostrand Reinhold. 
Koenigsberger, O.H, Ingersol O.H, T.G Mayhew. (1973). Manual of tropical housing and building, part one: Climatic design. London: Longman Group Limited.

Mangunwijaya, YB. (1992). Wastu citra. Jakarta: Gramedia Pustaka Utama.

Muhdi. A., Sangkertadi., \& Judy.O.W (2014). Kenyamanan termal pada sebuah rumah adat tradisional Gorontalo. Media Matrasain, 11(1). Retrieved from https://www.researchgate.net/publication/283506997

Niniek. P., Baharuddin H., \& Rosady.M. (2020). Komparasi performa insulasi termal antara dinding batu bata dan batu bata dengan penambahan insulasi alangalang. Jurnal Teknik, 18(1), 23-34. doi:10.37031/jt.v18i1.60

Rahmayanti. (2020). Pengaruh window to wall ratio terhadap kenyamanan fisiologis dengan menggunakan CFD ANSYS 14.0. Gorontalo Journal of Infrastructure and Science Engineering, 3(1), 37-43. doi:10.32662/gojise.v3i1.905

Sukawi. (2009). Aplikasi eko arsitektur pada rumah panggung dalam mengantisipasi kondisi termal lingkungan (Tinjauan konstruksi dan bahan bangunan), Lingkungan Tropis, edisi khusus Agustus 2009: 307316. Retrieved From http://eprints.undip.ac.id/32383/1/sukawi-eko_arsitektur_format.pdf 